\title{
The Reactivity of the Highly Functionalized Copper, Zinc Reagents \\ RCu(CN)ZnI Toward 1-Haloalkynes and Acetylenic Esters
}

\author{
Ming Chang P. Yeh and Paul Knochel*
}

Department of Chemistry, The University of Michigan, Ann Arbor, Michigan 48109

Summary: The highly functionalized organometallics $\mathrm{RCu}(\mathrm{CN}) \mathrm{ZnI} 1$ react efficiently with 1-haloalkynes providing polyfunctionalized alkynes in high yields. This method has been used to prepare a pheromone of the Amathes c-nigrum in 3 steps and $64 \%$ overall yield. The reagents 1 also add in the presence of an excess of $\mathrm{Me}_{3} \mathrm{SiCl}$ to acetylenic esters to afford polyfunctionalized $\mathrm{C}$ - silylated ethylenic esters. In the case of ethyl propiolate, the reaction is highly stereoselective and affords $97 \%$ pure (E)-2-trimethylsilyl ethylenic esters.

The high covalent character of the carbon-zinc bond allows the synthesis of highly functionalized organozinc compounds $\mathrm{RZnX} \mathrm{X}^{1,2}$ which can be converted to the corresponding copper derivatives $\mathrm{RCu}(\mathrm{CN}) \mathrm{ZnX} 1$ by the addition of the soluble copper salt $\mathrm{CuCN} \cdot 2 \mathrm{LiCl}{ }^{2}$ These copper reagents react efficiently with various electrophiles such as enones, allylic halides, acyl chlorides and aldehydes. ${ }^{2}$ We now report that the polyfuntional copper compounds 1 react under very mild conditions with 1-bromo- and 1-iodo-alkynes 3,4 2a-d affording the highly functionalized alkynes $3 a-3 j$ in good yields 5 (73-87\%; see Scheme I and Table I). The best results are obtained by performing the reactions at low temperature

\section{Scheme I}

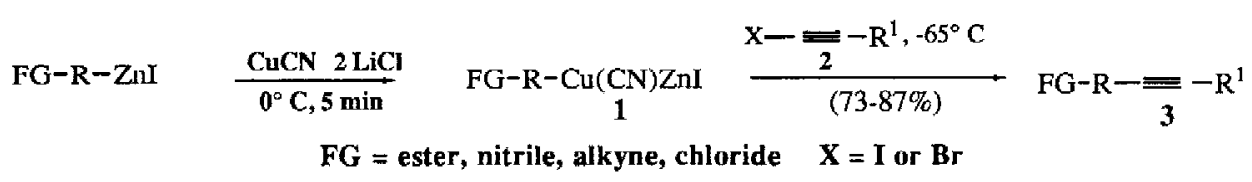

$\left(-78^{\circ} \mathrm{C}\right.$ to $\left.-55^{\circ} \mathrm{C}\right)$ in order to avoid halogen-metal exchange reactions, especially in the case of 1 -iodooctyne $2 \mathrm{~b}$. Under these conditions, reaction times of 16-18 hr. are usually required for the haloalkynes $2 \mathrm{a}-2 \mathrm{c}$. Noteworthy is the case of 1-bromo-2-phenylacetylene $2 \mathrm{~d}$ which affords the coupling products after much shorter reaction times $\left(1-4 \mathrm{hr}\right.$. at $\left.-78^{\circ} \mathrm{C}\right)$, indicating that the mechanism of the reaction may be an addition-elimination reaction involving a rate deternining syn carbocupration ${ }^{6}$ followed by an anti-elimination. Two of the polyfunctional alkynes produced (3f;3j) were converted to the corresponding iodides 4 and 5 in $82 \%$ and $79 \%$ yield respectively (NaI, acetone, 16 hr. reflux). Their reaction with zinc ( 2.5 equiv.) in THF $\left(40^{\circ} \mathrm{C}, 1 \mathrm{hr}\right.$, then $23^{\circ} \mathrm{C}, 16 \mathrm{hr}$.) furnishes, after hydrolysis, the cyclized olefins 6 and 7 in $73 \%$ and $75 \%$ yield respectively, 7 (see Scheme II). We have applied this methodology in a very short synthesis of the pheromone of the Amathes c-nigrum $8 .^{8}$ Thus the treatment of oxepane $(0.4 \mathrm{~mol})$ and $\mathrm{NaI}(0.5 \mathrm{~mol})$ at $0^{\circ} \mathrm{C}$ in acetonitrile with acetyl

\section{Scheme II}

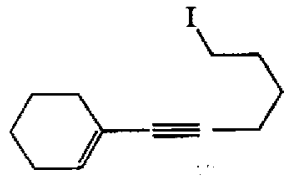

4

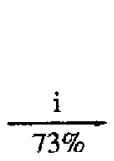

$\frac{1}{73 \%}$

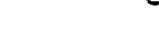

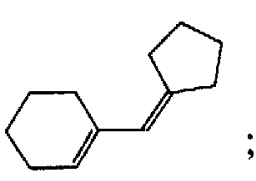

6

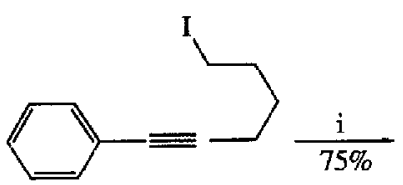

5

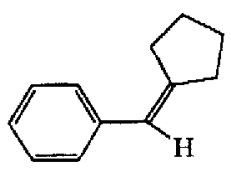

7

i: $\mathrm{Zn}(2.5 \mathrm{eq}), \mathrm{THF}, 40^{\circ} \mathrm{C}, 1 \mathrm{hr}$, then $16 \mathrm{hr}$ at $23^{\circ} \mathrm{C}$ 
Table I. Alkynes 3a-3j Obtained by the Reaction of RCu(CN)ZnI 1 with the 1-Haloalkynes 2a-2d.

\begin{tabular}{|c|c|c|c|c|}
\hline Entry & $\mathrm{RCu}(\mathrm{CN}) \mathrm{ZnI}$ & 1-Haloalkyne & Products 3 & Yield $(\%)^{\mathrm{a}}$ \\
\hline 1 & $\mathrm{NC}-\left(\mathrm{CH}_{2}\right)_{3}-\mathrm{Cu}(\mathrm{CN}) \mathrm{ZnI}$ & $\mathrm{Br}=-\mathrm{Hex} \quad 2 \mathbf{a}$ & $\mathrm{NC}-\left(\mathrm{CH}_{2}\right)_{3}-=-\mathrm{Hex} \quad 3 \mathrm{a}$ & 81 \\
\hline 2 & $\mathrm{EtO}_{2} \mathrm{C}-\left(\mathrm{CH}_{2}\right)_{3}-\mathrm{Cu}(\mathrm{CN}) \mathrm{ZnI}$ & $\mathrm{Br}-=-\mathrm{Hex} \quad \mathbf{2 a}$ & $\mathrm{EtO}_{2} \mathrm{C}-\left(\mathrm{CH}_{2}\right)_{3}=\mathrm{Hex} 3 \mathrm{~b}$ & 78 \\
\hline 3 & $\mathrm{c}-\mathrm{Hex} \mathrm{Cu}(\mathrm{CN}) \mathrm{ZnI}$ & $\mathrm{Br}=-\mathrm{Hex} \quad 2 \mathrm{a}$ & $\mathrm{c}-\mathrm{Hex}=-\mathrm{Hex} \mathbf{3 c}$ & 87 \\
\hline 4 & $\mathrm{CH}_{3}-\mathrm{CH}(\mathrm{OPiv})-\left(\mathrm{CH}_{2}\right)_{3}-\mathrm{Cu}(\mathrm{CN}) \mathrm{ZnI}$ & $\mathbf{I}=-\mathrm{Hex} 2 \mathbf{b}$ & $\mathrm{CH}_{3}-\mathrm{CH}(\mathrm{OPiv})-\left(\mathrm{CH}_{2}\right)$ & 75 \\
\hline 5 & $\mathrm{NC}-\left(\mathrm{CH}_{2}\right)_{3}-\mathrm{Cu}(\mathrm{CN}) \mathrm{ZnI}$ & & $\mathrm{NC}-\left(\mathrm{CH}_{2}\right)$ & 79 \\
\hline 6 & $\mathrm{Cl}-\left(\mathrm{CH}_{2}\right)_{4}-\mathrm{Cu}(\mathrm{CN}) \mathrm{ZnI}$ & & $\mathrm{Cl}-\left(\mathrm{CH}_{2}\right)_{4}$ & 81 \\
\hline 7 & $\mathrm{EtO}_{2} \mathrm{C}-\left(\mathrm{CH}_{2}\right)_{3}-\mathrm{Cu}(\mathrm{CN}) \mathrm{ZnI}$ & & 2 & 74 \\
\hline 8 & Pent $-=-\left(\mathrm{CH}_{2}\right)_{3}-\mathrm{Cu}(\mathrm{CN}) \mathrm{ZnI}$ & $\mathrm{Ph}=-\mathrm{Br} 2 \mathrm{~d}$ & Pent $-\equiv-\left(\mathrm{CH}_{2}\right)_{3}=-\mathrm{Ph} 3 \mathrm{~h}$ & 86 \\
\hline 9 & $\mathrm{EtO}_{2} \mathrm{C}-\left(\mathrm{CH}_{2}\right)_{3}-\mathrm{Cu}(\mathrm{CN}) \mathrm{ZnI}$ & $\mathrm{Ph}=-\mathrm{Br} \mathbf{2 d}$ & $\mathrm{EtO}_{2} \mathrm{C}-\left(\mathrm{CH}_{2}\right)_{3}=-\mathrm{Ph} 3 \mathbf{i}$ & 73 \\
\hline 10 & $\mathrm{Cl}-\left(\mathrm{CH}_{2}\right)_{4}-\mathrm{Cu}(\mathrm{CN}) \mathrm{ZnI}$ & $\mathrm{Ph}-\equiv-\mathrm{Br} 2 \mathrm{~d}$ & $\mathrm{Cl}-\left(\mathrm{CH}_{2}\right)_{4}=-\mathrm{Ph} \mathbf{3 j}$ & 71 \\
\hline
\end{tabular}

a Isolated yields of analytically pure products. Sarisfactory spectral data (IR, ${ }^{1} \mathrm{H}$ and ${ }^{13} \overline{\mathrm{C}-N M R}$, High resolution mass spectra) were obtained for all new compounds.

chloride $(0.5 \mathrm{~mol})$ affords, after distillation, 1 -acetoxy-6-iodohexane in $82 \%$ yield. ${ }^{9}$ This iodide was converted into 6-acetoxyhexylzinc iodide ( $3 \mathrm{eq}$. of zinc activated with dibromoethane, $2 \mathrm{a} 40^{\circ} \mathrm{C}, 10 \mathrm{hr}$.) in over $95 \%$ yield. Formation of the corresponding copper derivatives $\left(\mathrm{CuCN} \cdot 2 \mathrm{LiCl}, 0^{\circ} \mathrm{C}, 5 \mathrm{~min}\right.$.) and coupling with 1-iodooctyne $\left(0.77 \mathrm{eq} .,-78^{\circ} \mathrm{C}\right.$, then $16 \mathrm{hr}$. at $-50^{\circ} \mathrm{C}$ ) affords 7 -tetradecyn-1-yl acetate 9 in $81 \%$ isolated yield (10 mmol scale experiment). Lindlar hydrogenation $\left(\mathrm{H}_{2}, 1 \mathrm{~atm}, \mathrm{Pd} / \mathrm{CaCO}_{3} / \mathrm{PbO}\right.$; toluene/pyridine $\left.=6 / 1,0^{\circ} \mathrm{C}, 48 \mathrm{hr}\right)$ of 9 gives the desired pheromone 8 with over $99.4 \%$ in $98 \%$ yield ( $>99.4 \% \mathrm{Z}$, see Scheme III).

During this study, we also found that the functionalized copper reagents 1 are able to react with acetylenic esters of type $10^{10}$ under well defined conditions, affording either the ethylenic esters 11, the C-silylated unsaturated esters 12 or a mixture of both ${ }^{11}$ (see Scheme IV and Table II). Ethyl propiolate 10a reacts readily with FG-R-Cu(CN)ZnI $1\left(-78^{\circ} \quad \mathrm{C}\right.$, 1-14 hr.) to afford the pure (E)-ethylenic esters 11 (see entries 1 and 3 of Table II). In the presence of an excess of $\mathrm{Me}_{3} \mathrm{SiCl}^{12}$ the (E)-silylated product 12 is obtained exclusively in very high stereoisomeric purity ( $>97 \% \mathrm{E}$ ) and in excellent yields (see entries 2,4 , and 5). In the case of substituted acetylenic esters such as $10 \mathrm{~b}$ and $10 \mathrm{c}$, the presence of $\mathrm{Me}_{3} \mathrm{SiCl}^{12}$ is required for addition and with methyl tetrolate $(10 \mathrm{c})$, the formation of silylated products of type 12 usually predominates (a mixture of $E$ and $Z$ stereoisomers is formed; see entries 9-11). The bulkier ester 10b allows better control 
Scheme III

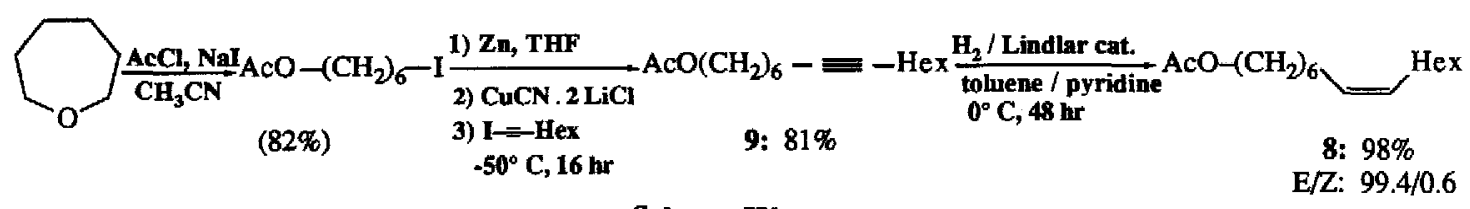

\section{Scheme IV}

E/Z: $99.4 / 0.6$

$$
\begin{aligned}
\mathrm{FG}-\mathrm{R}-\mathrm{Cu}(\mathrm{CN}) \mathrm{ZnI}+ & \mathrm{R}^{1}=-\mathrm{CO}_{2} \mathrm{R}^{2} \stackrel{\mathrm{Me}_{3} \mathrm{SiCl}}{1} \\
& 10 \mathrm{a}: \mathrm{R}^{1}=\mathrm{H} ; \mathrm{R}^{2}=\mathrm{Et} \\
& 10 \mathrm{~b}: \mathrm{R}^{1}=\mathrm{Hex} ; \mathrm{R}^{2}=\mathrm{Me} \\
& 10 \mathrm{c}: \mathrm{R}^{1}=\mathrm{Me} ; \mathrm{R}^{2}=\mathrm{Me}
\end{aligned}
$$

\begin{tabular}{|c|c|c|c|c|c|c|c|}
\hline Entry $\mathrm{FG}-\mathrm{R}-\mathrm{Cu}(\mathrm{CN}) \mathrm{ZnI}$ & $\begin{array}{l}\text { Acetylenic } \\
\text { ester }\end{array}$ & $\begin{array}{l}\text { No. of equiv. } \\
\mathrm{Me}_{3} \mathrm{SiCl} \text { added }\end{array}$ & $\begin{array}{l}\text { Prod } \\
\mathrm{R}^{1}\end{array}$ & $\begin{array}{l}\text { Iucts } \\
\mathrm{R}^{2}\end{array}$ & $\begin{array}{c}11 \text { and (or) } 12 \\
\text { FG-R- }\end{array}$ & $\begin{array}{l}\text { Ratio } \\
11: 12\end{array}$ & $\begin{array}{l}\text { Yield } \\
(\%)^{\mathrm{a}}\end{array}$ \\
\hline $1 \mathrm{NC}-\left(\mathrm{CH}_{2}\right)_{3}-\mathrm{Cu}(\mathrm{CN}) \mathrm{ZnI}$ & $10 a$ & 0 & $\mathbf{H}$ & $\mathrm{Et}$ & $\mathrm{NC}-\left(\mathrm{CH}_{2}\right)_{3}-$ & $100: 0$ & $83^{b}$ \\
\hline $2 \mathrm{NC}-\left(\mathrm{CH}_{2}\right)_{3}-\mathrm{Cu}(\mathrm{CN}) \mathrm{ZnI}$ & $10 \mathrm{a}$ & 4 & $\mathbf{H}$ & Et & $\mathrm{NC}\left(\mathrm{CH}_{2}\right)_{3-}^{-}$ & $0: 100$ & $84^{b}$ \\
\hline $3 \mathrm{EtO}_{2} \mathrm{C}-\left(\mathrm{CH}_{2}\right)_{3}-\mathrm{Cu}(\mathrm{CN}) \mathrm{ZnI}$ & $10 a$ & 0 & $\mathrm{H}$ & Et & $\mathrm{EtO}_{2} \mathrm{C}-\left(\mathrm{CH}_{2}\right)_{3}-$ & $100: 0$ & $99 b$ \\
\hline $4 \mathrm{EtO}_{2} \mathrm{C}-\left(\mathrm{CH}_{2}\right)_{3}-\mathrm{Cu}(\mathrm{CN}) \mathrm{ZnI}$ & $10 \mathbf{a}$ & 4 & $\mathrm{H}$ & $\mathrm{Et}$ & $\mathrm{EtO}_{2} \mathrm{C}-\left(\mathrm{CH}_{2}\right)_{3}-$ & $0: 100$ & $91^{b}$ \\
\hline $5 \mathrm{Cl}-\left(\mathrm{CH}_{2}\right)_{4}-\mathrm{Cu}(\mathrm{CN}) \mathrm{ZnI}$ & $10 \mathbf{a}$ & 4 & $\mathrm{H}$ & Et & $\mathrm{Cl}-\left(\mathrm{CH}_{2}\right)_{4}-$ & $0: 100$ & $85^{b}$ \\
\hline $6 \mathrm{NC}-\left(\mathrm{CH}_{2}\right)_{3}-\mathrm{Cu}(\mathrm{CN}) \mathrm{ZnI}$ & $10 b$ & 2 & Hex & $\mathrm{Me}$ & $\mathrm{NC}-\left(\mathrm{CH}_{2}\right)_{3}-$ & $100: 0$ & $82^{f}$ \\
\hline 7 & $10 \mathrm{~b}$ & 5 & Hex & $\mathrm{Me}$ & & $100: 0$ & $77 \mathrm{c}, \mathrm{f}$ \\
\hline 8 & 10b & 4 & Hex & $\mathrm{Me}$ & $\mathrm{I}_{23}-$ & $22: 78$ & $73^{\mathrm{d}, \mathrm{f}}$ \\
\hline Pivo & $10 \mathrm{c}$ & 4 & $\mathrm{Me}$ & Me & & $12: 88$ & $78 f$ \\
\hline $10 \mathrm{AcO}-\left(\mathrm{CH}_{2}\right)_{6}-\mathrm{Cu}(\mathrm{CN}) \mathrm{ZnI}$ & $10 \mathrm{c}$ & 1.6 & $\mathrm{Me}$ & $\mathrm{Me}$ & $\mathrm{AcO}-\left(\mathrm{CH}_{2}\right)_{6-}^{-}$ & $17: 81$ & $76^{e, f}$ \\
\hline $11 \mathrm{BuCu}(\mathrm{CN}) \mathrm{ZnI}$ & $10 \mathrm{c}$ & 4 & $\mathrm{Me}$ & $\mathrm{Me}$ & $\mathrm{Bu}$ & $9: 91$ & $85^{f}$ \\
\hline
\end{tabular}

Table II. Ethylenic Esters 11 and 12 Obtained by the Addition of RCu(CN)ZnI 1 to the Acetylenic Esters 10a-c.

a Isolated yields of analytically pure products. Satisfactory spectral data (IR, ${ }^{1} \mathrm{H}$ and ${ }^{13} \mathrm{C}-\mathrm{NMR}$, High resolution mass spectra) were obtained for all new compounds. $b$ The (E)-isomer was isolated ( $>97 \%$ stereoisomeric purity). c A reaction time of $3 \mathrm{hr}$ at $22^{\circ} \mathrm{C}$ was used. d A reaction time of $18 \mathrm{hr}$ at $22^{\circ} \mathrm{C}$ was used. $\mathrm{e}$ The reaction was performed in the presence of two eq. of $\mathrm{BF}_{3} \cdot \mathrm{OEt}_{2}$. $\mathrm{f}$ Obtained as a $\mathrm{E} / \mathrm{Z}$ mixture of isomers. 
of the reaction and affords only the unsilylated product 11 if either short reaction times $\left(3 \mathrm{hr}\right.$. at $23^{\circ} \mathrm{C}$ ) or a small excess of $\mathrm{Me}_{3} \mathrm{SiCl}$ are used. 13 With longer reaction times $\left(18 \mathrm{hr}\right.$. at $22^{\circ} \mathrm{C}$ ), the $\mathrm{C}$ - silylated ester 12 is again the major product (compare entries 7 and 8 ). The use of $\mathrm{BF}_{3} \cdot \mathrm{OEt}_{2}$ does not improve this selectivity (see entry 10). Further synthetic applications of these and related reactions are currently being studied.

Acknowledgments: We thank the National Institutes of Health (GM 41908) and the Horace H. Rackham School of Graduate Studies of The University of Michigan for the generous support of this work.

References. 1.(a) Tamaru, Y.; Ochiai, H.; Nakamura, T.; Tsubaki, K.; Yoshida, Z. Tetrahedron Lett. 1985, 26, 5559; (b) Tamaru, Y.; Ochiai, H.; Nakamura, T.; Yoshida, Z. Tetrahedron Lett. 1986, 27, 955; (c) Nakamura, E.; Sekiya, K.; Kuwajima, I.; Tetrahedron Lett. 1987, 28, 337; (d) El Alami, N.; Belaud, C.; Villeras, J. J. Organomet. Chem. 1987, 319, 303; (e) Comins, D.L., O'Connor, S. Tetrahedron Lett. 1987, 28, 1843; (f) Comins, D.L.; Foley, M.A. Tetrahedron Lett. 1988, 29, 6711; (g) Tamaru, Y.; Ochiai, H.; Nakamura, T.; Yoshida, Z. Angew Chem. 1987, 99, 1193; ibid, Angew. Chem. Int. Ed. Engl. 1987, 26, 1157.

2. (a) Knochel, P.; Yeh, M.C.P.; Berk, S.C.; Talbert, J.J. Org. Chem. 1988, 53, 2390; (b) Yeh, M.C.P.; Knochel, P.; Santa, L.E. Tetrahedron Lett. 1988, 29, 2395; (c) Yeh, M.C.P.; Knochel, P.; Santa, L.E. Tetrahedron Lett. 1988, 29, 3887; (d) Yeh, M.C.P.; Knochel, P.; Butler, W.M.; Berk, S.C. Tetrahedron Lett. 1988, 29, 6693; (e) Berk, S.C.; Knochel, P.; Yeh, M.C.P. J. Org. Chem. 1988, 53, 5791.

3. For the preparation of bromo- and iodo-alkynes see; Brandsma, L., Preparative Acetylenic Chemistry, Elsevier, Amsterdam, London and New York, 1971, p. 99.

4. Lithium and magnesium copper compounds react with 1-iodo and 1-bromoalkynes giving the substituted alkynes in fair to good yields: (a) Oliver, R.; Walton, D.R.M. Tetrahedron Lett. 1972, 5209; (b) Waugh, F,; Walton, D.R.M. J. Organomet. Chem. 1972, 39, 275; (c) Commercon, A.; Normant, J.F.; Villieras, J. Tetrahedron 1980, 36, 1215; (d) Stang, P.J.; Kitamura, T. J. Am. Chem. Soc. 1987, 109, 7561.

5. Typical procedure: A THF solution of 4-chlorobutylzinc iodide ( $7 \mathrm{mmol}) ; 1.4 \mathrm{eq}$. prepared in over $90 \%$ from 4-chloro1 -iodobutane $2 \mathrm{a}\left(40^{\circ} \mathrm{C}, 2 \mathrm{hr}\right.$. then $23^{\circ} \mathrm{C}, 10 \mathrm{hr}$ ), was added at $-10^{\circ} \mathrm{C}$ to a solution of $\mathrm{CuCN} \cdot 2 \mathrm{LiCl}(7 \mathrm{mmol})$ in THF (7 ml). After $5 \mathrm{~min}$. at $0^{\circ} \mathrm{C}$, the yellow-green solution was cooled to $-78^{\circ} \mathrm{C}$ and $925 \mathrm{mg}(5 \mathrm{mmol})$ of the 1 -bromoalkyne $2 \mathrm{~b}$ in THF was slowly added. The reaction mixture was stirred $18 \mathrm{hr}$ at $-65^{\circ} \mathrm{C}$. After the usual work-up and purification by flash chromatography (solvent: hexane), $800 \mathrm{mg}$ of pure $3 \mathrm{f}$ was obtained ( $81 \%$ yield).

6. The easy carbocupration of phenylacetylene is well known: Normant, J.F.; Alexakis, A. Synthesis 1981, 841.

7. Careful monitoring of these reactions did not allow us to detect an intermediate open-chain organozinc compound. The addition of $\mathrm{CuCN} \cdot 2 \mathrm{LiCl}$ followed by an excess of allyl bromide before hydrolysis did not afford any allylated product in the case of the alkyne 5 and led to a 1:1 mixture of the allylated and non-allylated of 6 indicating a partial or complete loss of the metal during the cyclization. This can be explained by a radical mechanism. The radical cyclization of 5 promoted by Bu3 SnH (1.1 eq.) in benzene $\left(0.05 \mathrm{~N}\right.$ solution, AIBN cat. $80^{\circ} \mathrm{C}, 30 \mathrm{~min}$ ) proceeds less efficiently than with zinc and affords a 58:42 ratio of the cyclized product 7 and of the reduced open-chain alcyne (1-phenylhexyne) in 65\% yield; see (a) Beckwith, A.L.J.; Roberts, D.H.J. Am. Chem. Soc. 1986, 108, 5893 and references cited therein; (b) Porter, N.A.; Magnin, D.R.; Wright, B.T. J. Am. Chem. Soc.1986, 108, 2787.

8. (a) Ando, T.; Yoshida, S.; Tatsuki, S.; Takahashi, N. Agric. Biol. Chem. 1977, 41, 1485; (b) Bestmann, H.J.; Vostrowsky, O.; Platz, H.; Brosche, T.; Koschatzky, K.H.; Knauf, W. Tetrahedron Lett, 1979, 497; (c) Brown, H.C.; Basavaiah, D.; Singh, S.M.; Bhat, N.G. J. Org. Chem. 1988, 53, 246.

9. Oku, A.; Harada, T.; Kita, K. Tetrahedron Lett. 1982, 23, 681.

10. The addition of lithium, copper reagents to alkynyl esters has been well studied: (a) Corey, E.J.; Katzenellenbogen, I.A. I. Am. Chem. Soc 1969, 9I, 1851; (b) Marino, J.P.; Linderman, R.J. J. Org. Chem. 1981, 46, 3696.

11. Typical procedure: A THF solution of 3-cyano propylzinc iodide $(7 \mathrm{mmol})$ was added at $-10^{\circ} \mathrm{C}$ to a solution of 630 $\mathrm{mg}$ ( $7 \mathrm{mmol})$ of $\mathrm{CuCN}$ and of $590 \mathrm{mg}(14 \mathrm{mmol})$ of $\mathrm{LiCl}$ in $8 \mathrm{~mL}$ of THF. The slightly green solution obtained, was cooled to $-78^{\circ} \mathrm{C}$ and $2.5 \mathrm{~mL}$ ( $20 \mathrm{mmol}$ ) of $\mathrm{Me}_{3} \mathrm{SiCl}$ and $490 \mathrm{mg}(5 \mathrm{mmol})$ of ethyl propiolate was added. The reaction was allowed to warm to $23^{\circ} \mathrm{C}$ and stirred $17 \mathrm{hr}$. at this temperature. After the usual work-up, $1.00 \mathrm{~g}(4.2 \mathrm{mmol})$ of pure (E)-ethyl 6-cyano-2-trimethylsilyl-2-hexenoate $(84 \%$ yield) was obtained. The stereochemistry of the double bond was established by an ${ }^{1} \mathrm{H}-\mathrm{NMR}$ NOE experiment. (Irradiation of the vinylic proton at $6.18 \mathrm{ppm}$ gave a strong enhancement of the methyl peak at $0.12 \mathrm{ppm}$ )

12. (a) Chuit, C.; Foulon, J.P.; Normant, J.F. Tetrahedron 1981, 27, 1385; 1980, 36, 2305. (b) Bourgain-Commercon, M.; Foulon, J.P.; Normant, J.F. J. Organomet. Chem. 1982, 228, 321. (c) Corey, E.J.; Boaz, N.W. Tetrahedron Lett. 1985, 26,6015, 6019. (d) Alexakis, A.; Berlan, J.; Besace, Y. Tetrahedron Lett. 1986, 27, 1047. (e) Horiguchi, Y.; Matsuzawa, S.; Nakamura, E.; Kuwajima, I. Tetrahedron Lett. 1986, 27, 4025. (f) Nakamura, E.; Matsuzawa, S.; Horiguchi, Y.; Kuwajima, I. Tetrahedron Lett. 1986, 27, 4029.

13. We verified that the formation of the $\mathrm{C}$ - silylated ester 12 is not due to the presence of zinc cations and the reaction of $\mathrm{BuCu}(\mathrm{CN}) \mathrm{Li}$ with $10 \mathrm{c}$ in the presence of $\mathrm{Me}_{3} \mathrm{SiCl}\left(2\right.$ equiv., $23^{\circ} \mathrm{C}, 24 \mathrm{hr}$.) affords the same ratio of 11:12 as observed with $\mathrm{BuCu}(\mathrm{CN}) \mathrm{ZnI}$ (entry 7). 